\title{
The Plateau Exhibition in Ghent 2001
}

\author{
By Ron Holloway
}

Spring 2002 Issue of KINEMA

\section{THE PLATEAU EXHIBITION AT THE SCIENCE MUSEUM IN GHENT 2001}

Film historians with a tick for the archaeology of the cinema are well advised to pay a visit to the Museum of Science in Ghent to view the exhibition honouring the 200th birthday of Belgian scientist Joseph Plateau. It was Plateau's experiments on optical deception and the persistence of vision in the middle of the 19th century that led to the invention of the anorthoscope (distorted view) and the phenakistiscope (deceitful view), the direct precursors of the first moving picture inventions. The entire range of related optical inventions the stroboscope (whirling view), the thaumatrope (magical turning), and zoetrope (life turning), to name just the key scientific discoveries that led to cinematography were placed on mechanically driven display at the opening of the 28th Flanders International Film Festival in Ghent (8-18 October 2001).

Visitors to the Flanders festival were also presented with an invaluable catalogue to accompany the exhibition: "Joseph Plateau, (1801-1883) Living Between Art and Science" (Gent: Provincie Oost-Vlaanderen, 2001) by Maurice Dorikens, with additional essays by David Robinson, Laurent Mannoni, and Giusy Pisno-Basile. Robinson's contribution on "Plateau, Faraday and Their Spinning Discs" focuses on the fruitful competition between Joseph Plateau in Belgium and Michael Faraday in England on experiments relating to optical deception. Plateau won that race by a few months to perfect the anorthoscope in 1936, a concession readily made by Faraday upon reading the Belgian scientist's published papers.

To Robinson's credit, however, he offers well researched evidence that Faraday's 1830 paper on his own experiments influenced in turn the invention of the phenakistiscope in 1832, a scientific honour shared in the end by Joseph Plateau in Belgium and Simon Stempfer in Austria. Also, you can forget that canard about the dedicated Belgian scientist blinding himself by staring at the sun to test the effects of optical stimulus on his cornea. Maurice Dorikens and the Plateau Exhibition document that Plateau's eventual blindness stemmed mostly from natural causes.

If some of that odd-sounding classical terminology for rather ordinary looking cut-outs, cranks-and-screws, whirling-discs, and spinning-tops muddles the waters of modern-day rational comprehension, then know that the 19th-century wizards had tipped their hats to the Greek mathematician Ptolemy. Nearly two centuries ago, he observed how a coloured portion of a revolving disc tinted the whole surface the first factual recording of the phenomenon of persistence of vision. This said, some historians wonder why the "movies" took so long to be discovered as the seventh art.

\section{Author Information}

Ron HOLLOWAY (1933-2009) was an American critic, film historian, filmmaker and correspondent who adopted Europe as his home in the early fifties and spent much of his life in Berlin. He was an expert on the study of German cinema and against all odds produced, with his wife Dorothea, the journal German Film, keeping us up-to-date with the work of directors, producers and writers and the showing of German films around the world.

In 2007, Ron Holloway and his wife were awarded the Berlinale Camera Award. Ron also received the Bundesverdienstkreuz (German Cross of Merit), Polish Rings, Cannes Gold Medaille, the American Cinema Foundation Award, the Diploma for Support of Russian Cinema and an honorary award from the German Film Critics' Association.

Ron was also a valued contributor to Kinema for the past fifteen years. 